\title{
Cold snare polypectomy of large lesions: One swallow does not a summer make
}

Referring to Tate DJ et al. p. 248-252

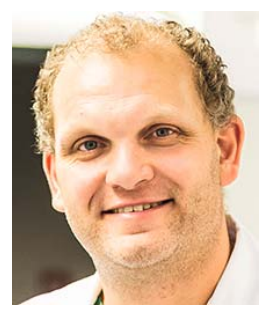

Leon M. G. Moons

Author

Leon M. G. Moons

Institution

Department of Gastroenterology and Hepatology,

University Medical Center Utrecht, Utrecht, The

Netherlands
Bibliography

DOI https://doi.org/10.1055/s-0044-100494

Endoscopy 2018; 50: 200-202

(c) Georg Thieme Verlag KG Stuttgart · New York

ISSN 0013-726X

Corresponding author

Leon M. G. Moons, MD, PhD, University Medical Center

Utrecht - Gastroenterology and Hepatology,

Heidelberglaan 100 , Utrecht 3508GA, The Netherlands

Fax: +31-88-7555081

I.m.g.moons@umcutrecht.nl
In this issue of Endoscopy, Tate et al. [1] report on the safety of piecemeal cold snare polypectomy (pCSP) of 41 sessile serrated polyps (SSPs) $\geq 10 \mathrm{~mm}$ in the colon. CSP is nowadays the preferred technique for removal of diminutive polyps as it safe, very effective, fast, and allows proper histological assessment. Although at first it was reserved for polyps of $<5 \mathrm{~mm}$, recent papers support the use of CSP for small polyps up to $10 \mathrm{~mm}$. The idea of expanding the limits of CSP to polyps $\geq 10 \mathrm{~mm}$, as examined by Tate et al., is attractive because post-polypectomy complications, including delayed bleeding, post-polypectomy syndrome, and perforation, are thought to be associated with thermal injury to either submucosal vessels or the muscle layer.

\section{Hot versus cold snare polypectomy}

In the last few years, multiple randomized studies have demonstrated that CSP of polyps of $5-10 \mathrm{~mm}$ in size is non-inferior to hot snare polypectomy (HSP) with regard to complete resection rate ( $\triangleright$ Table 1 ) [2-4]. Although none of these studies demonstrated a significant difference in post-polypectomy bleeding between the arms, this complication was only observed in the HSP groups [2 -4]. Although it seems logical from a theoretical perspective that CSP should be the technique of choice for the resection of polyps of $<10 \mathrm{~mm}$, the real safety benefit for small polyps is negligible. As the risk of bleeding as well as perforations increases with the size of the polyp, the safety profile of CSP may become more beneficial with increasing polyp size.

\section{Comparison with earlier studies of CSP on polyps of $\geq 10 \mathrm{~mm}$}

The study of Tate et al. builds on earlier studies of pCSP for large polyps ( $>$ Table2), which followed on from a case report describing successful pCSP of a $45-\mathrm{mm}$ polyp in the proximal colon in a high risk 83-year-old patient [5]. The technique used in most studies consists of submucosal lifting with saline, with or without epinephrine, followed by PCSP ( also referred to as piecemeal cold snare endoscopic mucosal resection (pCS-EMR).

\section{" $p$ CSP seems particularly promising for SSPS of $\geq 10 \mathrm{~mm}$ in the proximal colon and perhaps also for adenomas in patients with a high risk of post-polypectomy bleeding"}

In the study of Tate, pCSP was performed without submucosal lifting, which of course decreases costs and time. Although submucosal lifting could potentially help in delineating the borders of the polyp and perhaps the size of the fragments to be resected with CSP, the small number of cases does not permit a formal comparison between the two techniques. Future studies should address this technical issue. 
- Table 1 Overview of studies on cold snare versus hot snare polypectomy of polyps sized 5-10 mm.

\begin{tabular}{|c|c|c|c|c|c|}
\hline Study (Year) & Design & $\begin{array}{l}\text { Complete } \\
\text { resection rate }\end{array}$ & $\begin{array}{l}\text { Intraprocedural } \\
\text { bleeding }\end{array}$ & $\begin{array}{l}\text { Delayed post- } \\
\text { polypectomy } \\
\text { bleeding }\end{array}$ & $\begin{array}{l}\text { Difference in } \\
\text { polypectomy or } \\
\text { procedure time }\end{array}$ \\
\hline Ichise (2011) [2] & $\begin{array}{l}\text { RCT of polyps } \leq 8 \mathrm{~mm}: \\
\text { CSP }(n=101) \text { vs. HSP } \\
(n=104)\end{array}$ & $96 \%$ vs. $96 \%$ & - & $0 \%$ vs $0 \%$ & 18 vs. 25 minutes \\
\hline $\begin{array}{l}\text { Kawamura (2017) } \\
\text { [3] }\end{array}$ & $\begin{array}{l}\text { RCT of polyps } 4-9 \mathrm{~mm} \text { : } \\
\text { CSP }(n=341) \text { vs. HSP } \\
(n=346)\end{array}$ & $98 \%$ vs. $97 \%$ & $7.1 \%$ vs. $3.5 \%$ & $0 \%$ vs. $0.5 \%$ & 60 vs. 83 seconds \\
\hline $\begin{array}{l}\text { Papastergiou } \\
\text { (2017) [4] }\end{array}$ & $\begin{array}{l}\text { RCT of polyps } 6-10 \mathrm{~mm} \text { : } \\
\operatorname{CSP}(n=83) \text { vs. } \operatorname{HSP}(n=81)\end{array}$ & $93 \%$ vs. $96 \%$ & $3.6 \%$ vs. $1.2 \%$ & $0 \%$ vs $0 \%$ & NA \\
\hline
\end{tabular}

CSP, cold snare polypectomy; HSP: hot snare polypectomy; RCT, randomized controlled trial; NA, not available.

- Table 2 Overview of observational cohort studies on piecemeal cold snare polypectomy (pCSP)/endoscopic mucosal resection (EMR) of polyps $>10 \mathrm{~mm}$.

\begin{tabular}{|c|c|c|c|c|c|c|c|c|c|}
\hline $\begin{array}{l}\text { Study } \\
\text { (Year) }\end{array}$ & Design (n) & Technique & $\begin{array}{l}\text { Median } \\
\text { size } \\
\text { (range), } \\
\text { mm }\end{array}$ & $\begin{array}{l}\text { Type of } \\
\text { polyps }\end{array}$ & $\begin{array}{l}\text { Techni- } \\
\text { cal } \\
\text { success } \\
\text { rate }\end{array}$ & $\begin{array}{l}\text { Intra- } \\
\text { procedural } \\
\text { bleeding }\end{array}$ & $\begin{array}{l}\text { Delayed } \\
\text { post-poly- } \\
\text { pectomy } \\
\text { bleeding }\end{array}$ & $\begin{array}{l}\text { Recur- } \\
\text { rence }\end{array}$ & $\begin{array}{l}\text { Adjunctive } \\
\text { treatment }\end{array}$ \\
\hline $\begin{array}{l}\text { Tate } \\
(2017) \\
{[1]}\end{array}$ & $\begin{array}{l}\text { Prospective } \\
(n=41)\end{array}$ & $\mathrm{pCSP}$ & $\begin{array}{l}15 \\
(10-35)\end{array}$ & SSP & $100 \%$ & $0 \%$ & $0 \%$ & $0 \%$ & No \\
\hline $\begin{array}{l}\text { Tutticci, } \\
\text { (2017) } \\
{[6]}\end{array}$ & $\begin{array}{l}\text { Prospective } \\
(n=163)\end{array}$ & pCS-EMR & $\begin{array}{l}15 \\
(10-40)\end{array}$ & SSP & $100 \%$ & $0.6 \%$ & $0 \%$ & $0.6 \%$ & No \\
\hline $\begin{array}{l}\text { Piraka, } \\
\text { (2015) } \\
{[7]}\end{array}$ & $\begin{array}{l}\text { Retrospec- } \\
\text { tive }(n=94)\end{array}$ & pCS-EMR & $\begin{array}{l}20 \\
(12-60)\end{array}$ & $\begin{array}{l}\text { Adenoma } \\
\text { and serra- } \\
\text { ted polyps }\end{array}$ & $100 \%$ & $1.1 \%$ & $0 \%$ & $9.7 \%$ & $\begin{array}{l}\text { Forceps } \\
\text { use ( } 29 \%)\end{array}$ \\
\hline $\begin{array}{l}\text { Muniraj } \\
(2015) \\
{[8]}\end{array}$ & $\begin{array}{l}\text { Retrospec- } \\
\text { tive }(n=30)\end{array}$ & pCS-EMR & $19( \pm 8)^{1}$ & $\begin{array}{l}\text { Adenoma } \\
\text { and serra- } \\
\text { ted polyps }\end{array}$ & $100 \%$ & $0 \%$ & $0 \%$ & $20 \%$ & $\begin{array}{l}\text { APC (30\%) } \\
\text { and/or } \\
\text { hemoclips }\end{array}$ \\
\hline $\begin{array}{l}\text { Barros } \\
(2014) \\
{[9]}\end{array}$ & $\begin{array}{l}\text { Prospective } \\
(n=43)\end{array}$ & $\mathrm{pCSP}$ & $(10-20)$ & $\begin{array}{l}\text { Adenoma } \\
\text { and serra- } \\
\text { ted polyps }\end{array}$ & $100 \%$ & $0 \%$ & $0 \%$ & -2 & -2 \\
\hline
\end{tabular}

\section{Safety of cold snare polypectomy/EMR for polyps of $\geq 10 \mathrm{~mm}$}

The risk of post-polypectomy bleeding after EMR of large sessile serrate polyps (SSPs; median size $30 \mathrm{~mm}$, range 20 - 35) was reported to be $5.7 \%$ in another article by the same Australian group [10]. In the current study by Tate et al., the median size was $15 \mathrm{~mm}$ with an interquartile range (IQR) of $14.5-20 \mathrm{~mm}$, meaning that the vast majority of lesions were smaller than 20 $\mathrm{mm}$, and $50 \%$ were even smaller than $15 \mathrm{~mm}$.

No post-polypectomy bleeding was observed in any of the 34 patients, but with an expected risk of post-polypectomy bleeding somewhere between $2 \%-5 \%$ for these relatively small polyps, only one bleeding episode would have been expected within this cohort, even with EMR using coagulation. The study of Tate et al. is therefore not designed to examine superior safety in terms of post-polypectomy bleeding. However, taking all the currently reported studies together, 129 polyps were $>20 \mathrm{~mm}$, and at least 39 polyps were $>30 \mathrm{~mm}$, and in none of these cases was post-polypectomy bleeding observed. This gives strong support to the assumption that pCSP may indeed have a superior safety profile. 


\section{Effectiveness of CSP for polyps of}

\section{$\geq 10 \mathrm{~mm}$}

Choosing an adequate resection technique is however also a balancing act between safety and effectiveness. The risk of recurrence requires follow-up endoscopies, and recurrence is associated with post-colonoscopy colorectal carcinomas.

Increasing polyp size has been identified as a risk factor for incomplete resection in previous trials on CSP. Although the vast majority of lesions in the current study were relatively small, the median number of pieces in which the polyp was removed was 3.0 (IQR 3-5), which seems rather high considering the size of the lesions. Piecemeal resections are associated with an increased risk of local recurrence and the risk increases with the number of pieces removed. It was previously shown that wide-field pEMR, taking out an additional rim of normal tissue, was unable to decrease the risk of recurrence. If this is true, why should wide-field CSP be more effective?

Currently, both the American Society for Gastrointestinal Endoscopy (ASGE) and the European Society for Gastrointestinal Endoscopy (ESGE) advise performing a follow-up endoscopy within 3-6 months after piecemeal resection. As polyps $<20 \mathrm{~mm}$ can be safely removed en bloc with EMR in $>90 \%$ of cases and it is also associated with a low risk of perforation and post-polypectomy bleeding $[11,12]$, it is questionable whether the limited safety benefit for polyps of $10-20 \mathrm{~mm}$ outweighs the necessity of a follow-up endoscopy for these polyps. This is especially true for adenomas, as both studies in which adenomas were included showed comparable recurrence rates for PCSP and PEMR with coagulation.

Although very few incomplete resections were observed for SSPs, data on long-term follow-up are still lacking. It is therefore too early to draw clear conclusions on the long-term effectiveness of pCSP. If the low risk of recurrence is confirmed after longer follow-up, CSP may then also become the preferred technique for SSPs $\geq 10 \mathrm{~mm}$ and for all polyps $\geq 20 \mathrm{~mm}$ in the proximal colon as a piecemeal resection is inevitable for polyps of this size.

\section{Advanced imaging}

The decision to use PCSP for polyps of $\geq 20 \mathrm{~mm}$ requires the use of advanced imaging. The efficacy of endoscopic polypectomy is not only related to the risk of recurrence but also to the ability of the pathologists to evaluate the specimen. This not only concerns evaluation of the resection margin of the lateral borders, but also the presence of submucosal invasion. The discrimination of high grade dysplasia and submucosal invasion is based on the location of severely dysplastic cells below or above/in the muscularis mucosa. Fragmentation and loss of orientation resulting from piecemeal resection hinder accurate histological discrimination. The fragments removed with PCSP are 8-10 $\mathrm{mm}$ in size, as larger pieces may preclude efficient tissue transection, thereby causing more fragmentation than EMR. Moreover, CSP also results in a very superficial cut through the submucosa or deep mucosa. Protrusions are observed in the center after CSP in approximately $22 \%-50 \%$ of cases $[1,4]$. Histology of these protrusions shows submucosa, but also muscularis mucosa in $38 \%$ of cases [4]. The incidence of high grade dysplasia increases with the size of the polyp, and thorough pre-resection assessment of the polyp should be performed to prevent pCSP being carried out on an SSP with dysplasia or an adenoma with high grade dysplasia.

Is there enough evidence to introduce pCSP for polyps of $\geq 10 \mathrm{~mm}$ at this moment in daily practice? At this moment, PCSP seems particularly promising for SSPs of $\geq 10 \mathrm{~mm}$ in the proximal colon and perhaps also for adenomas in patients with a high risk of post-polypectomy bleeding. However, adenomas $10-20 \mathrm{~mm}$ in size should not be removed with pCSP, and the suspicion of dysplasia in SSPs also precludes the use of pCSP.

\section{Competing interests}

None

References

[1] Tate DJ, Awadie H, Bahin FF et al. Wide-field piecemeal cold snare polypectomy of large sessile serrated polyps without a submucosal injection is safe. Endoscopy 2017; 50: 248-252

[2] Ichise $Y$, Horiuchi A, Nakayama Y et al. Prospective randomized comparison of cold snare polypectomy and conventional polypectomy for small colorectal polyps. Digestion 2011; 84: $78-81$

[3] Kawamura T, Takeuchi Y, Asai S et al. A comparison of the resection rate for cold and hot snare polypectomy for 4-9 mm colorectal polyps: a multicentre randomised controlled trial (CRESCENT study). Gut doi:10.1136/gutjnl-2017-314215

[4] Papastergiou V, Paraskeva KD, Fragaki M et al. Cold versus hot endoscopic mucosal resection for nonpedunculated colorectal polyps sized 6-10 mm: a randomized trial. Endoscopy doi:10.1055/s-0043118594

[5] Barros RA, Monteverde M], Barros RF et al. Cold snare resection of a nonpolypoid lesion >45 mm. Gastrointest Endosc 2014; 80: 1176 1177

[6] Tutticci NJ, Hewett DG. Cold endoscopic mucosal resection of large sessile serrated polyps at colonoscopy (with video). Gastrointest Endosc doi:10.1016/j.gie.2017.11.002

[7] Piraka C, Saeed A, Waljee AK et al. Cold snare polypectomy for nonpedunculated colon polyps greater than $1 \mathrm{~cm}$. Endosc Int Open 2017; 5: E184-E189

[8] Muniraj T, Sahakian A, Ciarleglio MM et al. Cold snare polypectomy for large sessile colonic polyps: a single-center experience. Gastroenterol Res Pract 2015 2015: 175959

[9] Augusto Barros R, Monteverde M], Federico Barros R et al. [Safety and efficacy of cold snare resection of non-polypoid colorectal lesions ( 0 Ila and 0-IIb)]. Acta Gastroenterol Latinoam 2014; 44: 27 - 32

[10] Pellise M, Burgess NG, Tutticci N et al. Endoscopic mucosal resection for large serrated lesions in comparison with adenomas: a prospective multicentre study of 2000 lesions. Gut 2017; 66: 644-653

[11] Belderbos TD, Leenders M, Moons LM et al. Local recurrence after endoscopic mucosal resection of nonpedunculated colorectal lesions: systematic review and meta-analysis. Endoscopy 2014; 46: 388-402

[12] Horiuchi A, Makino T, Kajiyama M et al. Comparison between endoscopic mucosal resection and hot snare resection of large nonpedunculated colorectal polyps: a randomized trial. Endoscopy 2016; 48: $646-651$ 